\title{
Association of Gestational Diabetes Mellitus in Women with Polycystic Ovary Syndrome and Evaluation of Role of Metformin in Reducing the Risk
}

\author{
Fauzia Haq Nawaz and Tahira Naru \\ Aga Khan University Hospital \\ Pakistan
}

\section{Introduction}

\subsection{Objective}

To evaluate the prevalence of gestational diabetes mellitus (GDM) in women with polycystic ovary syndrome (PCOS) and to investigate the efficacy of Metformin in reduction of gestational diabetes in women with polycystic ovary syndrome.

\subsection{Design}

Review of literature on prevalence of gestational diabetes and evaluation of efficacy of Metformin in reducing the prevalence of gestational diabetes in women with polycystic ovary syndrome.

\subsection{Setting}

Reproductive Endocrinology section of Department of Obstetrics and Gynecology of Aga Khan University Hospital Karachi Pakistan.

\subsection{Patient(s)}

Women with PCOS and gestational diabetes

\subsection{Intervention(s)}

Literature search in the electronic databases MEDLINE, study of the references of all relevant trials or reviews, and manual search of the abstracts from the major meetings in the field of human reproduction.

\subsection{Main outcome measure}

Odds Ratio( OR) for the occurrence of gestational Diabetes. 


\subsection{Result(s)}

Women with PCOS demonstrated a significantly higher risk for the development of GDM as compared with women without PCOS

\subsection{Description}

The Polycystic Ovarian Syndrome (PCOS) is a common endocrinopathy, affecting approximately $5-10 \%$ of women of reproductive age. In its classical form, the syndrome is characterized by oligo- or anovulation, biochemical or clinical hyperandrogenismand polycystic ovarian morphology on ultrasonography. Although much remains unknown regarding the underlying path physiology of PCOS, a form of insulin resistance intrinsic to the syndromeappears to play a central role in its development. Among many women with PCOS, the observed insulin resistance is partially explained by excess adiposity; however, it is increasingly recognized that even lean women with PCOS have increased insulin resistance compared with normal controls. Affected women have an increased risk of glucose intolerance, gestational diabetes mellitus (GDM) and type 2 diabetes. Some, studies suggest the risk of GDM is higher among PCOS versus non-PCOS women, and several studies note an increased prevalence of polycystic ovarian morphology and symptoms in women with prior GDM.

Insulin resistance is defined as the decreased ability of insulin to stimulate glucose disposal into target tissues, or a reduced glucose response to a given amount of insulin. Chronic hyperinsulinemia is a compensatory response to this target tissue resistance. Several mechanisms have been suggested to explain insulin resistance, including peripheral target tissue resistance, decreased hepatic clearance, or increased pancreatic sensitivity. The peripheral insulin resistance in PCOS is uniquely due to a defect beyond the activation of the receptor kinase, namely, reduced tyrosine autophosphorylation of the insulin receptor and enhances the expression of hyperandrogenism by its inhibitory effect on hepatic sex hormone binding globulin (SHBG) production thereby increasing the bioavailability of androgens which leads to metabolic and obstetrical complications. Significant metabolic burden of insulin resistance is seen in women with PCOS, affected women may have an increased risk of impaired glucose tolerance (IGT), GDM and type 2 diabetes mellitus (DM).

In pregnant women with PCOS, the increasing tissue resistance to insulin, mainly caused by placental hormones, adds on the preexisting state of insulin resistance, which may accompany the syndrome. This pathogenic mechanism could lead to hyperglycemia, reflected in a higher incidence of GDM. However, studies on GDM prevalence in women with PCOS gave conflicting results; considering the heterogeneity of PCOS and the diversity in methodology of screening and diagnosing GDM, these results should have been expected.

A method of combining the results of the studies addressing the risk of Incidence of GDM in women with PCOS was one of the endpoints in addressing pregnancy complications in women with PCOS. Women with PCOS demonstrated a significantly higher chance of the development of GDM, though with significant statistical heterogeneity among the studies. This heterogeneity was not further analyzed or accounted for. To examine whether women with PCOS have a greater risk for the development of GDM than women without PCOS, we performed a review of literature and analysis of available trial 


\section{PCOS, Gestational Diabetes Mellitus (GDM) and diabetes}

It has been recognized that women with PCOS have a higher risk for developing type 2 diabetes mellitus and gestational diabetes .In a retrospective cohort follow-up of patients with PCOS, the prevalence of diabetes mellitus was 7-fold higher than in controls.

Gestational diabetes is defined as impaired glucose tolerance diagnosed for the first time during pregnancy, occurs in $2-5 \%$ of pregnancies and usually resolves at the end of gestation. However, between one half and one third of women with gestational diabetes may develop diabetes 2-11 years post-partum. Different studies have shown that women with PCOS have a higher risk for the development of gestational diabetes in relation to insulin resistance. Moreover, other authors have demonstrated a high incidence of polycystic ovaries in women with history of gestational diabetes Gestational diabetes is associated with a high neonatal morbidity and given that patients with PCOS have a high prevalence of gestational diabetes, these women should be considered to be at risk. Therefore, preventive measures before pregnancy to minimize neonatal morbidity should be recommended, including dietary advice and physical exercise as well as to indicate insulinsensitizing treatments before; and during pregnancy.

In reproductive age, the prevalence of type 2 diabetes mellitus is estimated between 1.7 and $6.1 \%$. This prevalence would be expected to be from 5-10-fold higher in women with PCOS. On the other hand, PCOS may be considered a pre-diabetic state with a prevalence of impaired glucose tolerance of $31-35 \%$ and a prevalence of type 2 diabetes of $7.5-10 \%$. Impaired glucose tolerance is characterized by moderate increases of fasting glucose levels that may precede diabetes. Women with impaired glucose tolerance are asymptomatic; therefore, an oral glucose tolerance test is required for diagnosis. Conversion of impaired glucose tolerance to frank diabetes in women with PCOS is $5-10$ times more frequent compared with normal women The mean age at diagnosis of type 2 diabetes mellitus in patients with PCOS (30-40 years of age) is lower than in normal women (60-70 years of age) Additionally, a family history of diabetes and the presence of obesity are important predictors for the development of type 2 diabetes mellitus.

The diagnostic criteria of diabetes based on the 1999 World Health Organization definition and the 1997 recommendations of the Expert Committee of the ADA is a fasting glucose level $\geq 126 \mathrm{mg} / \mathrm{dl}(7 \mathrm{mmol} / \mathrm{l})$ or oral glucose tolerance test ( $2 \mathrm{~h}$ plasma glucose after $75 \mathrm{~g}$ oral glucose challenge) $\geq 200 \mathrm{mg} / \mathrm{dl}(11.1 \mathrm{mmol} / \mathrm{l})$. Diagnostic criteria of impaired glucose tolerance include normal fasting glucose levels $(<126 \mathrm{mg} / \mathrm{dl})$ in association with oral glucose tolerance test $\geq 140$ and $<200 \mathrm{mg} / \mathrm{dl}(7.8-11.1 \mathrm{mmol} / \mathrm{l})$. Normal baseline plasma glucose levels are $110 \mathrm{mg} / \mathrm{dl}(6.1 \mathrm{mmol} / \mathrm{l})$. The principal difference between the 1997 ADA criteria and the 1999 WHO criteria is that the ADA criteria discourage the use of the oral glucose tolerance test as a routine diagnostic tool whereas the WHO criteria do not. However, it seems that the WHO criteria are more adequate for the diagnosis of diabetes in women with PCOS tolerance test .

These data indicate that women with PCOS are at high risk for long-term development of type 2 diabetes mellitus, and support the importance of an early diagnosis and treatment of insulin resistance to help reduce the incidence and severity of diabetes, dyslipidemia, hypertension and cardiovascular disease 


\section{Review of role of insulin sensitizing agents (metformin) in prevention of gestational diabetes in women with pcos}

A major change in the treatment of PCOS was initiated by the understanding that many women with this disorder compensate insulin resistance with a period of hyper secretion of insulin by the pancreatic beta cell. This understanding has been incorporated into the framework of PCOS treatments through the beneficial effects of insulin-sensitizing treatments on the PCOS phenotype Agents that improve insulin sensitivity (and lower circulating insulin levels) include metformin as well as thiazolidinediones, pioglitazone and rosiglitazone as alternative pharmacotherapies for those who cannot tolerate metformin as a result of gastrointestinal side effects. These treatments have resulted in beneficial changes in PCOS phenotype with increased menstrual and ovulatory frequency, pregnancy and decreased hirsutism. On the other hand, an increase in obstetrical pathology in women with PCOS has been documented, including increased rates of miscarriage, gestational diabetes, macrosomia, caesarean deliveries and pre-eclampsia. Given that hyperinsulinaemia may play a role in the pathophysiology of these conditions, maintenance of oral antidiabetic agents during pregnancy may decrease the incidence of these complications. Metformin, with a high safety profile for use during pregnancy, has been given to pregnant women with PCOS resulting in a reduction of the aforementioned conditions in these patients.

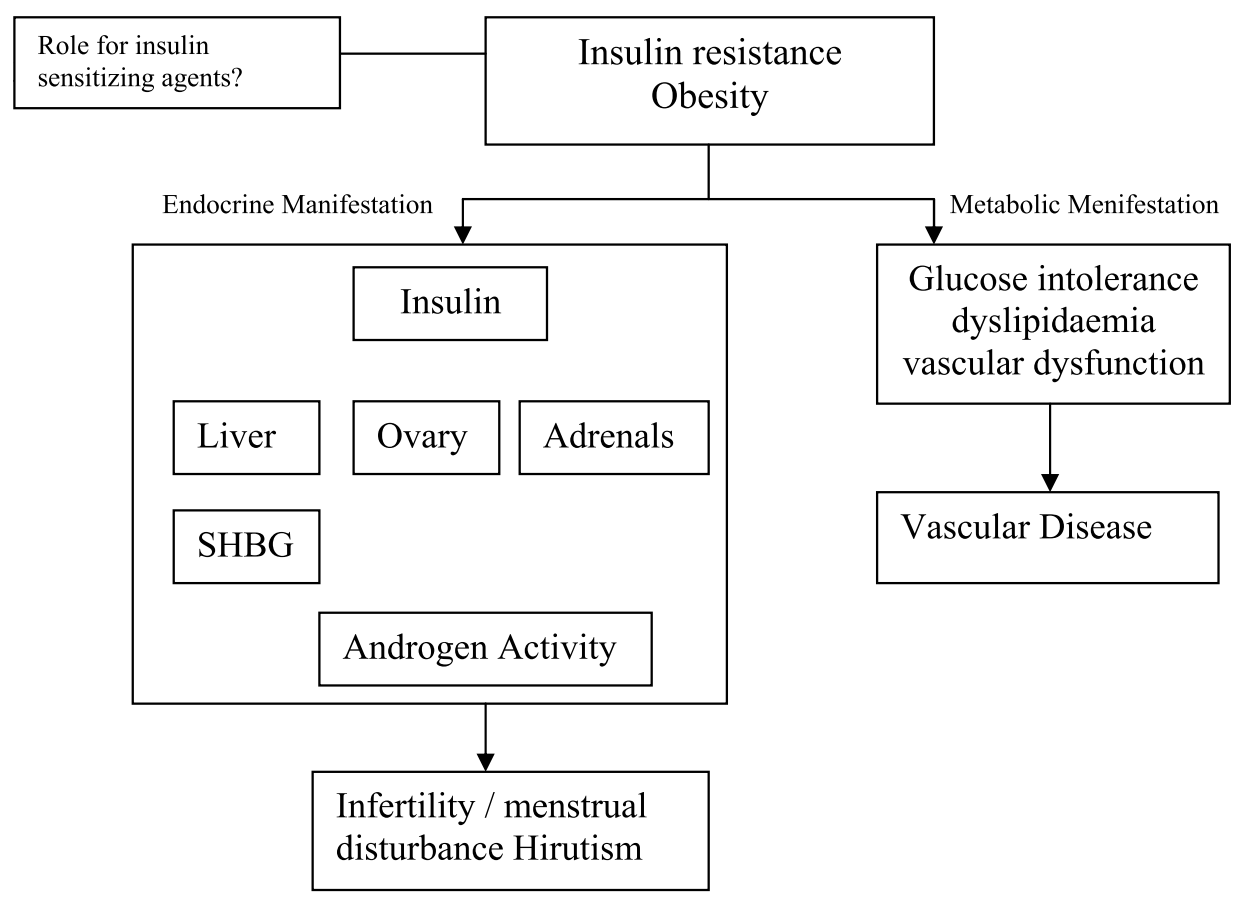

Fig. 1. Postulated role for insulin sensitizing agents on target tissues affected in woman with PCOS Harborne L etal 
These concepts have quickly become the cornerstone of diagnosis and treatment of PCOS and other diseases also associated with insulin resistance. Type 2 diabetes mellitus and gestational diabetes. Recent observations regarding the effect of insulin-sensitizing drugs on ovarian stimulation in patients with PCOS undergoing IVF are also discussed, as well as the current status of the use of insulin-sensitizing drugs during pregnancy. Finally, substantial progress has been made to elucidate the cellular and molecular mechanisms of insulin resistance in PCOS. The insulin receptor and genetics of PCOS are complex areas that are extensively being investigated.

These agents increase the tissue sensitivity to insulin action in vivo .The agent commonly used in clinical practice is metformin, an oral hypoglycemic biguanide. Newer agents include the thiazolidinediones group of drugs like troglitazone. Hepatotoxocity of this drug has lead to its withdrawal, but pioglitazone and D-chiroinositol has been used with some success in an insulin sensitization in women with PCOS

\subsection{Metformin}

It acts primarily by increasing peripheral glucose uptake in response to insulin at post receptor level, with some basal reduction in gluconeogenesis. It improves the insulin sensitivity in adipose tissues and skeletal muscles. All of the action are mediated by CAMP activated by protein kinase .It has been suggested that various insulin sensitizing drugs specifically inhibits the 17,20 lyase activity of P450c 17 . While it true that these drugs lower the $\mathrm{C} 19$ steroids but still the exact mechanism of action of metformin is not clear.

Until now the use of insulin sensitizing agents are targeted toward symptoms and signs of PCOS, like in ovulation induction, as an anti androgen therapy and for hirsutism. In this chapter we will be discussing the role of insulin sensitizers particularly metformin in prevention of Gestational diabetes associated with PCOS in light of recent evidence support.

\subsection{Use of metformin and prevention and treatment of gestational diabetes mellitus}

Metformin has been used to treat diabetes in second and third trimesters of pregnancy after the main teratogenic period, no significant perinatal morbidity and mortality was noticed except relatively high frequency of neonatal jaundice. Coetzee et al.14, has published the experience of 118 pregnant women with PCOS, who received an oral hypoglycemic medication and found the higher frequency of preeclampsia and perinatal mortality. However when these study results were critically analyzed it was found these women were older, more obese than their reference group which accounted for the baseline characteristics rather than Metformin alone.

The incidence of gestational diabetes in women with PCOS appears to be increased but data are not consistent .Insulin resistance in PCOS and the inability of pancreatic beta cells to compensate for increased needs of insulin during pregnancy are risk factors for gestational diabetes.

Different studies have documented a decrease in the incidence of gestational diabetes in PCOS women treated with metformin during pregnancy. Although in most of them retrospective controls were used. Prospective randomized studies with a sufficient number of patients are necessary in order to provide good evidence to recommend the use of metformin during pregnancy. 


\section{Conclusion}

PCOS is one of the most common hormonal disorder affecting women and has reproductive, metabolic, cardiovascular health implications across the life span. Insulin resistance in PCOS has been considered as main etiological factor for major health related consequences. Significant heterogeneity among studies and dependence of the outcome on study type make the higher risk of GDM in women with PCOS a questionable finding. The conduction of properly designed studies should precede any recommendation to pregnant women with PCOS in regard to the risk of GDM.

\section{Refrences}

[1] 1997 Report of the Expert Committee on the Diagnosis and Classification of Diabetes Mellitus. Diabetes Care 20:1183-1197

[2] 1998 Will new diagnostic criteria for diabetes mellitus change phenotype of patients with diabetes? Reanalysis of European epidemiological data. DECODE Study Group on behalf of the European Diabetes Epidemiology Study Group. BMJ 317:371-375

[3] American Association of Clinical Endocrinologists Polycystic Ovary Syndrome Writing Committee 2005 American Association of Clinical Endocrinologists Position Statement on Metabolic and Cardiovascular Consequences of Polycystic Ovary Syndrome. Endocr Pract 11:126-134

[4] American Diabetes Association 2007 Standards of medical care in diabetes-2007. Diabetes Care 30(Suppl 1):S4-S41

[5] American Diabetes Association 2007 Standards of medical care in diabetes-2007. Diabetes Care 30(Suppl 1):S4-S41

[6] Arslanian SA, Lewy V, Danadian K, Saad R 2002 Metformin therapy in obese adolescents with polycystic ovary syndrome and impaired glucose tolerance: amelioration of exaggerated adrenal response to adrenocorticotropin with reduction of insulinemia/insulin resistance. J Clin Endocrinol Metab 87:15551559

[7] Arslanian SA, Lewy VD, Danadian K 2001 Glucose intolerance in obese adolescents with polycystic ovary syndrome: roles of insulin resistance and $\beta$-cell dysfunction and risk of cardiovascular disease. J Clin Endocrinol Metab 86:66-71

[8] Asuncion M, Calvo RM, San Millan JL, Sancho J, Avila S, Escobar-Morreale HF 2000 A prospective study of the prevalence of the polycystic ovary syndrome in unselected Caucasian women from Spain. J Clin Endocrinol Metab 85:2434-2438

[9] Azziz R, Carmina E, Dewailly D, Diamanti-Kandarakis E, Escobar-Morreale HF, Futterweit W, Janssen OE, Legro RS, Norman RJ, Taylor AE, Witchel SF, Androgen Excess Society 2006 Positions statement: criteria for defining polycystic ovary syndrome as a predominantly hyperandrogenic syndrome: an Androgen Excess Society guideline. J Clin Endocrinol Metab 91:4237-4245

[10] Azziz R, Woods KS, Reyna R, Key TJ, Knochenhauer ES, Yildiz BO 2004 The prevalence and features of the polycystic ovary syndrome in an unselected population. J Clin Endocrinol Metab 89:2745-2749 
[11] Baillargeon JP, Diamanti-Kandarakis E, Ostlund Jr RE, Apridonidze T, Iuorno MJ, Nestler JE 2006 Altered D-chiro-inositol urinary clearance in women with polycystic ovary syndrome. Diabetes Care 29:300-305

[12] Baillargeon JP, Iuorno MJ, Jakubowicz DJ, Apridonidze T, He N, Nestler JE 2004 Metformin therapy increases insulin-stimulated release of D-chiro-inositolcontaining inositolphosphoglycan mediator in women with polycystic ovary syndrome. J Clin Endocrinol Metab 89:242-249

[13] Barrett-Connor E, Ferrara A 1998 Isolated postchallenge hyperglycemia and the risk of fatal cardiovascular disease in older women and men. The Rancho Bernardo Study. Diabetes Care 21:1236-1239

[14] Boomsma CM, Eijkemans MJ, Hughes EG, Visser GH, Fauser BC, Macklon NS 2006 A meta-analysis of pregnancy outcomes in women with polycystic ovary syndrome. Hum Reprod Update 12:673-683

[15] Bridger T, MacDonald S, Baltzer F, Rodd C 2006 Randomized placebo-controlled trial of metformin for adolescents with polycystic ovary syndrome. Arch Pediatr Adolesc Med 160:241-246

[16] Centers for Disease Control and Prevention (CDC) 2003 Prevalence of diabetes and impaired fasting glucose in adults-United States, 1999-2000. MMWR Morb Mortal Wkly Rep 52:833-837

[17] Chen X, Yang D, Li L, Feng S, Wang L 2006 Abnormal glucose tolerance in Chinese women with polycystic ovary syndrome. Hum Reprod 21:2027-2032

[18] Chiasson JL, Josse RG, Gomis R, Hanefeld M, Karasik A, Laakso M 2002 Acarbose for prevention of type 2 diabetes mellitus: the STOP-NIDDM randomised trial. Lancet 359:2072-2077

[19] Coetzee EJ and Jackson WP .Oral hypoglycemic in the first trimester and fetal out come .S Afr Med J 1984; 65: 635-637

[20] Denburg MR, Manibo AM, Lobo RA, Jaffe R, Ferin M, Levine LS, Oberfield SE 2003 Early endocrine, metabolic, and sonographic characteristics of polycystic ovary syndrome (PCOS): comparison between nonobese and obese adolescents. J Clin Endocrinol Metab 88:4682-4688

[21] Dereli D, Dereli T, Bayraktar F, Ozgen AG, Yilmaz C 2005 Endocrine and metabolic effects of rosiglitazone in non-obese women with polycystic ovary disease. Endocr J 52:299-308

[22] Diabetes Prevention Program Research Group 2003 Effects of withdrawal from metformin on the development of diabetes in the diabetes prevention program. Diabetes Care 26:977-980

[23] Diamanti-Kandarakis E, Kouli CR, Bergiele AT, Filandra FA, Tsianateli TC, Spina GG, Zapanti ED, Bartzis MI 1999 A survey of the polycystic ovary syndrome in the Greek island of Lesbos: hormonal and metabolic profile. J Clin Endocrinol Metab 84:4006-4011

[24] Dunaif A, Finegood DT $1996 \beta$-Cell dysfunction independent of obesity and glucose intolerance in the polycystic ovary syndrome. J Clin Endocrinol Metab 81:942-947 
[25] Dunaif A, Segal KR, Futterweit W, Dobrjansky A 1989 Profound peripheral insulin resistance, independent of obesity, in polycystic ovary syndrome. Diabetes 38:1165-1174

[26] Dunaif A, Segal KR, Shelley DR, Green G, Dobrjansky A, Licholai T 1992 Evidence for distinctive and intrinsic defects in insulin action in polycystic ovary syndrome. Diabetes 41:1257-1266

[27] Durbin RJ 2004 Thiazolidinedione therapy in the prevention/delay of type 2 diabetes in patients with impaired glucose tolerance and insulin resistance. Diabetes Obes Metab 6:280-285

[28] Ehrmann DA 2000 Glucose intolerance in the polycystic ovary syndrome: role of the pancreatic $\beta$-cell. J Pediatr Endocrinol Metab 13(Suppl 5):1299-1301

[29] Ehrmann DA, Barnes RB, Rosenfield RL, Cavaghan MK, Imperial J 1999 Prevalence of impaired glucose tolerance and diabetes in women with polycystic ovary syndrome. Diabetes Care 22:141-146

[30] Ehrmann DA, Kasza K, Azziz R, Legro RS, Ghazzi MN 2005 Effects of race and family history of type 2 diabetes on metabolic status of women with polycystic ovary syndrome. J Clin Endocrinol Metab 90:66-71

[31] Ek I, Arner P, Bergqvist A, Carlstrom K, Wahrenberg H 1997 Impaired adipocyte lipolysis in nonobese women with the polycystic ovary syndrome: a possible link to insulin resistance? J Clin Endocrinol Metab 82:1147-1153

[32] Ek I, Arner P, Ryden M, Holm C, Thörne A, Hoffstedt J, Wahrenberg H 2002 A unique defect in the regulation of visceral fat cell lipolysis in the polycystic ovary syndrome as an early link to insulin resistance. Diabetes 51:484-492

[33] Expert Panel on Detection, Evaluation, and Treatment of High Blood Cholesterol in Adults 2001 Executive Summary of The Third Report of The National Cholesterol Education Program (NCEP) Expert Panel on Detection, Evaluation, And Treatment of High Blood Cholesterol In Adults (Adult Treatment Panel III). JAMA 285:2486-2497

[34] Gabir MM, Hanson RL, Dabelea D, Imperatore G, Roumain J, Bennett PH, Knowler WC 2000 The 1997 American Diabetes Association and 1999 World Health Organization criteria for hyperglycemia in the diagnosis and prediction of diabetes. Diabetes Care 23:1108-1112

[35] Gerstein HC, Yusuf S, Bosch J, Pogue J, Sheridan P, Dinccag N, Hanefeld M, Hoogwerf B, Laakso M, Mohan V, Shaw J, Zinman B, Holman RR 2006 Effect of rosiglitazone on the frequency of diabetes in patients with impaired glucose tolerance or impaired fasting glucose: a randomised controlled trial. Lancet 368:1096-1105

[36] Goodarzi MO, Erickson S, Port SC, Jennrich RI, Korenman SG $2005 \beta$-Cell function: a key pathological determinant in polycystic ovary syndrome. J Clin Endocrinol Metab 90:310-315

[37] Heymsfield SB, Segal KR, Hauptman J, Lucas CP, Boldrin MN, Rissanen A, Wilding JP, Sjöström L 2000 Effects of weight loss with orlistat on glucose tolerance and progression to type 2 diabetes in obese adults. Arch Intern Med 160:1321-1326 
[38] Holte J, Gennarelli G, Wide L, Lithell H, Berne C 1998 High prevalence of polycystic ovaries and associated clinical, endocrine, and metabolic features in women with previous gestational diabetes mellitus. J Clin Endocrinol Metab 83:1143-1150

[39] Ibanez L, Potau N, Marcos MV, de Zegher F 2000 Treatment of hirsutism, hyperandrogenism, oligomenorrhea, dyslipidemia, and hyperinsulinism in nonobese, adolescent girls: effect of flutamide. J Clin Endocrinol Metab 85:32513255Silfen ME,

[40] Kaneko T, Wang PY, Tawata M, Sato 1998 A low carbohydrate intake before oral glucose-tolerance tests. Lancet 352:289

[41] Kinoshita T, Kato J 1990 Impaired glucose tolerance in patients with polycystic ovary syndrome (PCOS). Horm Res 33(Suppl 2):18-20

[42] Knochenhauer ES, Key TJ, Kahsar-Miller M, Waggoner W, Boots LR, Azziz R 1998 Prevalence of the polycystic ovary syndrome in unselected black and white women of the southeastern United States: a prospective study. J Clin Endocrinol Metab 83:3078-3082

[43] Knowler WC, Barrett-Connor E, Fowler SE, Hamman RF, Lachin JM, Walker EA, Nathan DM, Diabetes Prevention Program Research Group 2002 Reduction in the incidence of type 2 diabetes with lifestyle intervention or metformin. N Engl J Med 346:393-403

[44] Knowler WC, Hamman RF, Edelstein SL, Barrett-Connor E, Ehrmann DA, Walker EA, Fowler SE, Nathan DM, Kahn SE, Diabetes Prevention Program Research Group 2005 Prevention of type 2 diabetes with troglitazone in the Diabetes Prevention Program. Diabetes 54:1150-1156

[45] Koivunen RM, Juutinen J, Vauhkonen I, Morin-Papunen LC, Roukonen A, Tapanainen JS 2001 Metabolic and steroidogenic alterations related to increased frequency of polycystic ovaries in women with a history of gestational diabetes. J Clin Endocrinol Metab 86:2591-2599

[46] Kurioka H, Takahashi K, Miyazaki K 2007 Glucose intolerance in Japanese patients with polycystic ovary syndrome. Arch Gynecol Obstet 275:169-173

[47] Legro RS, Castracane VD, Kauffman RP 2004 Detecting insulin resistance in polycystic ovary syndrome: purposes and pitfalls. Obstet Gynecol Surv 59:141154

[48] Legro RS, Gnatuk CL, Kunselman AR, Dunaif A 2005 Changes in glucose tolerance over time in women with polycystic ovary syndrome: a controlled study. J Clin Endocrinol Metab 90:3236-3242Anttila L, Karjala K, Penttila RA, Ruutiainen K, Ekblad U 1998 Polycystic ovaries in women with gestational diabetes. Obstet Gynecol 92:13-16

[49] Legro RS, Kunselman AR, Dodson WC, Dunaif A 1999 Prevalence and predictors of risk for type 2 diabetes mellitus and impaired glucose tolerance in polycystic ovary syndrome: a prospective, controlled study in 254 affected women. J Clin Endocrinol Metab 84:165-169

[50] Lo JC, Feigenbaum SL, Escobar GJ, Yang J, Crites YM, Ferrara A 2006 Increased prevalence of gestational diabetes mellitus among women with diagnosed 
polycystic ovary syndrome: a population-based study. Diabetes Care 29:19151917

[51] Moghetti P, Castello R, Negri C, Tosi F, Perrone F, Caputo M, Zanolin E, Muggeo M 2000 Metformin effects on clinical features, endocrine and metabolic profiles, and insulin sensitivity in polycystic ovary syndrome: a randomized, double-blind, placebo-controlled 6-month trial, followed by open, long-term clinical evaluation. J Clin Endocrinol Metab 85:139-146

[52] Mohlig M, Floter A, Spranger J, Weickert MO, Schill T, Schlösser HW, Brabant G, Pfeiffer AF, Selbig J, Schöfl C 2006 Predicting impaired glucose metabolism in women with polycystic ovary syndrome by decision tree modelling. Diabetologia 49:2572-2579

[53] Nestler JE, Jakubowicz DJ, Reamer P, Gunn RD, Allan G 1999 Ovulatory and metabolic effects of D-chiro-inositol in the polycystic ovary syndrome. N Engl J Med 340:1314-1320

[54] Nestler JE, Sharma ST, Misleading effects of a low-carbohydrate diet on glucose intolerance testing in women with PCOS: a case report. Program of the 88th Annual Meeting of The Endocrine Society, Boston, MA, 2006, p 857 (Abstract P3844)

[55] Norman RJ, Mahabeer S, Masters S 1995 Ethnic differences in insulin and glucose response to glucose between white and Indian women with polycystic ovary syndrome. Fertil Steril 63:58-62

[56] Norman RJ, Masters L, Milner CR, Wang JX, Davies MJ 2001 Relative risk of conversion from normoglycaemia to impaired glucose tolerance or non-insulin dependent diabetes mellitus in polycystic ovarian syndrome. Hum Reprod 16:1995-1998

[57] Palmert MR, Gordon CM, Kartashov AI, Legro RS, Emans SJ, Dunaif A 2002 Screening for abnormal glucose tolerance in adolescents with polycystic ovary syndrome. J Clin Endocrinol Metab 87:1017-1023

[58] Pan XR, Li GW, Hu YH, Wang JX, Yang WY, An ZX, Hu ZX, Lin J, Xiao JZ, Cao HB, Liu PA, Jiang XG, Jiang YY, Wang JP, Zheng H, Zhang H, Bennett PH, Howard BV 1997 Effects of diet and exercise in preventing NIDDM in people with impaired glucose tolerance. The Da Qing IGT and Diabetes Study. Diabetes Care 20:537-544

[59] Ramachandran A, Snehalatha C, Mary S, Mukesh B, Bhaskar AD, Vijay V 2006 The Indian Diabetes Prevention Programme shows that lifestyle modification and metformin prevent type 2 diabetes in Asian Indian subjects with impaired glucose tolerance (IDPP-1). Diabetologia 49:289-297

[60] Rosenbaum D, Haber RS, Dunaif A 1993 Insulin resistance in polycystic ovary syndrome: decreased expression of GLUT-4 glucose transporters in adipocytes. Am J Physiol 264(2 Pt 1):E197-E202

[61] Rotterdam ESHRE/ASRM-Sponsored PCOS Consensus Workshop Group 2004 Revised 2003 consensus on diagnostic criteria and long-term health risks related to polycystic ovary syndrome. Fertil Steril 81:19-25 
[62] Saad R, Gungor N, Arslanian S 2005 Progression from normal glucose tolerance to type 2 diabetes in a young girl: longitudinal changes in insulin sensitivity and secretion assessed by the clamp technique and surrogate estimates. Pediatr Diabetes 6:95-99

[63] Sharma ST, Nestler JE 2006 Prevention of diabetes and cardiovascular disease in women with PCOS: treatment with insulin sensitizers. Best Pract Res Clin Endocrinol Metab 20:245-260

[64] Soderberg S, Zimmet P, Tuomilehto J, de Courten M, Dowse GK, Chitson P, Stenlund H, Gareeboo H, Alberti KG, Shaw J 2004 High incidence of type 2 diabetes and increasing conversion rates from impaired fasting glucose and impaired glucose tolerance to diabetes in Mauritius. J Intern Med 256:37-47

[65] The DREAM Trial Investigators 2006 Effect of ramipril on the incidence of diabetes. N Engl J Med 355:1551-1562

[66] The Rotterdam ESHRE/ASRM-Sponsored PCOS Consensus Workshop Group 2004 Revised 2003 consensus on diagnostic criteria and long-term health risks related to polycystic ovary syndrome (PCOS). Hum Reprod 19:41-47

[67] Tominaga M, Eguchi H, Manaka H, Igarashi K, Kato T, Sekikawa A 1999 Impaired glucose tolerance is a risk factor for cardiovascular disease, but not impaired fasting glucose. The Funagata Diabetes Study. Diabetes Care 22:920-924

[68] Torgerson JS, Hauptman J, Boldrin MN, Sjostrom L 2004 XENical in the prevention of diabetes in obese subjects (XENDOS) study: a randomized study of orlistat as an adjunct to lifestyle changes for the prevention of type 2 diabetes in obese patients. Diabetes Care 27:155-161

[69] Trolle B, Lauszus FF 2005 Risk factors for glucose intolerance in Danish women with polycystic ovary syndrome. Acta Obstet Gynecol Scand 84:1192-1196

[70] Tuomilehto J, Lindstrom J, Eriksson JG, Valle TT, Hämäläinen H, Ilanne-Parikka P, Keinänen-Kiukaanniemi S, Laakso M, Louheranta A, Rastas M, Salminen V, Uusitupa M, Finnish Diabetes Prevention Study Group 2001 Prevention of type 2 diabetes mellitus by changes in lifestyle among subjects with impaired glucose tolerance. N Engl J Med 344:1343-1350

[71] Unluhizarci K, Kelestimur F, Bayram F, Sahin Y, Tutus A 1999 The effects of metformin on insulin resistance and ovarian steroidogenesis in women with polycystic ovary syndrome. Clin Endocrinol (Oxf) 51:231-236

[72] Vrbikova J, Dvorakova K, Grimmichova T, Hill M, Stanicka S, Cibula D, Bendlova B, Starka L, Vondra K 2007 Prevalence of insulin resistance and prediction of glucose intolerance and type 2 diabetes mellitus in women with polycystic ovary syndrome. Clin Chem Lab Med 45:639-644

[73] Weerakiet S, Srisombut C, Bunnag P, Sangtong S, Chuangsoongnoen N, Rojanasakul A 2001 Prevalence of type 2 diabetes mellitus and impaired glucose tolerance in Asian women with polycystic ovary syndrome. Int J Gynaecol Obstet 75:177-184

[74] Wein P, Beischer N, Harris C, Permezel M 1999 A trial of simple versus intensified dietary modification for prevention of progression to diabetes mellitus in women with impaired glucose tolerance. Aust N Z J Obstet Gynaecol 39:162-166 
[75] WHO Study Group on Diabetes Mellitus 1985 Diabetes mellitus: report of a WHO study group. Geneva: World Health Organization

[76] Wing RR, Venditti E, Jakicic JM, Polley BA, Lang W 1998 Lifestyle intervention in overweight individuals with a family history of diabetes. Diabetes Care 21:350359

[77] World Health Organization 2006 Definition and diagnosis of diabetes mellitus and intermediate hyperglycemia: report of a WHO/IDF consultation. Geneva: World Health Organization 


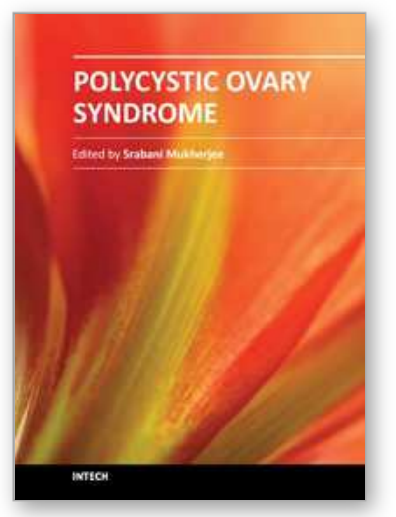

\author{
Polycystic Ovary Syndrome \\ Edited by Dr. Srabani Mukherjee
}

ISBN 978-953-51-0094-2

Hard cover, 168 pages

Publisher InTech

Published online 24, February, 2012

Published in print edition February, 2012

Brought into the limelight many decades ago, Polycystic Ovary Syndrome (PCOS) is still, to date, surrounded by controversy and mystery. Much attention has been attracted to various topics associated with PCOS research and there has been a healthy advance towards bettering the understanding of the many implications of this complex syndrome. A variety of topics have been dealt with by a panel of authors and compiled in this book. They span methods of diagnosis, reproductive anomalies, metabolic consequences, psychological mindset and ameliorative effects of various lifestyle and medical management options. These books are designed to update all associated professionals on the recent developments in this fast-growing field and to encourage further research into this thought-provoking subject.

\title{
How to reference
}

In order to correctly reference this scholarly work, feel free to copy and paste the following:

Fauzia Haq Nawaz and Tahira Naru (2012). Association of Gestational Diabetes Mellitus in Women with Polycystic Ovary Syndrome and Evaluation of Role of Metformin in Reducing the Risk, Polycystic Ovary Syndrome, Dr. Srabani Mukherjee (Ed.), ISBN: 978-953-51-0094-2, InTech, Available from: http://www.intechopen.com/books/polycystic-ovary-syndrome/association-of-gestational-diabetes-withpolycystic-ovarian-syndrome-

\section{INTECH}

open science | open minds

\author{
InTech Europe \\ University Campus STeP Ri \\ Slavka Krautzeka 83/A \\ 51000 Rijeka, Croatia \\ Phone: +385 (51) 770447 \\ Fax: +385 (51) 686166 \\ www.intechopen.com
}

\author{
InTech China \\ Unit 405, Office Block, Hotel Equatorial Shanghai \\ No.65, Yan An Road (West), Shanghai, 200040, China \\ 中国上海市延安西路65号上海国际贵都大饭店办公楼 405 单元 \\ Phone: +86-21-62489820 \\ Fax: $+86-21-62489821$
}


(C) 2012 The Author(s). Licensee IntechOpen. This is an open access article distributed under the terms of the Creative Commons Attribution 3.0 License, which permits unrestricted use, distribution, and reproduction in any medium, provided the original work is properly cited. 